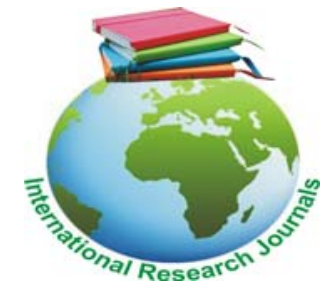

African Journal of Food Science and Technology ((ISSN: 2141-5455) Vol. 6(1) pp. 35-43, January, 2015

DOI: http:/dx.doi.org/10.14303/ajfst.2015.011

Available online @http://www.interesjournals.org/AJFST

Copyright (C2015 International Research Journals

\author{
Full Length Research Paper
}

\title{
Storage effects and the postharvest quality of African star apple fruits (Chrysophyllum africanum) under ambient conditions
}

\author{
*Florence Abolaji Bello and Adiaha Abigail Henry \\ Department of Food Science and Technology, University of Uyo, Uyo, Akwa Ibom State, Nigeria. \\ ${ }^{*}$ Corresponding Author E-mail: florenceabello@uniuyo.edu.ng; Phone: +234(0)8038578180
}

\begin{abstract}
Fruits constitute an important part of a balanced diet as they are natural sources of food nutrients. Most of the harvested produce ordinarily is left lying on the farm and at home. These plant nutrients degraded shortly after harvesting as a result of biochemical changes. The effect of storage after harvesting on African star apple fruit at ambient temperature $\left(28 \pm 2^{\circ} \mathrm{C}\right)$ was investigated on alternate days $(1,3$ and 5$)$. Its pulp, peel and seed were investigated in terms of their proximate composition, vitamin $C$, mineral elements and antinutrients using standard analytical techniques. The results showed a significant $(p<0.05)$ difference in the percentage proximate composition of African star apple fruit pulp and peel while there was no significant $(p>0.05)$ difference in moisture and crude protein of the seed at the storage days 1,3 and 5 . Greater percentage increase of moisture and crude fat contents were observed in the pulp and peel while there were decreases in the moisture, ash, crude protein and crude fibre contents of the seed in the storage days. The vitamin $C$ content of the African star apple fruit pulp, peel and seed was significantly $(p<0.05)$ different as storage progressed. There was a significant $(p<0.05)$ difference in mineral content of the African star apple pulp, peel and seed. Greater amount of sodium, potassium and magnesium were detected in the seed while pulp contain higher amount of calcium. The antinutrient composition decreased significantly $(p<0.05)$ in the pulp, peel and seed as the days progressed. African star apple fruit has a great potential in improving human health and as supplement in food formulation.
\end{abstract}

Keywords: Antinutrient, fruit, mineral, star apple, postharvest, proximate.

\section{INTRODUCTION}

Food security, health and the socio-economic welfare of both rural and urban communities have been sustained through non-timber forest products such as fruits, seeds, roots, stems, leaves and flowers (FAO, 1989). Fruits constitute important parts of a balanced diet as they are natural sources of food nutrients namely: protein, carbohydrate, minerals and dietary fibre, needed by man and animals. African star apple (Chrysophyllum africanum) an indigenous plant is an edible tropical fruit known by various tribal names in Nigeria as agbalumo (Yoruba), udara (Ibo, Efik and Ibibio), ehya (Igala) and agwaluma (Hausa). It is classified as a wild plant and belongs to the family, Sapotaceae. Chrysophyllum is a genus of about $70-80$ species of tropical trees native to tropical regions throughout the world, with the greatest number of species in the Northern South America and some parts of Africa (Arindam et al., 2010). It is a tree with great potentials not only as a plantation species, but also in agro- forestry system (Okigbo, 1978, Okafor, 1981).

African star apple (Chrysophyllum africanum) fruit is of great economic value due to its diverse industrial, medicinal and food uses. The fruits are not only consumed fresh but also used to produce jam, jellies, stewed fruit, marmalade, syrup and several types of soft drinks. It is also used for medical purposes due to properties of stalk and fruits. The leaves and seed of some of these fruits and vegetables are used in 
pharmaceuticals. Some of the trees are also valuable for ornamentation as an ever green broadleaf plant (Islam, 2002).

Several researchers (Achinewhu, 1983; Edem et al., 1984; Adewusi, 1997; Adisa, 2000; Amusa et al., 2003; Egunyomi, et al., 2005; Akubugwo and Ugboku, 2007; Ugbogu and Akukwe, 2008; Duyilemi and Lawal, 2009; Oboh et al., 2009; Adebayo et al., 2010 and Adewoye et al., 2010) have reported the nutritional and medicinal importance of $C$. albidum. In spite of the wide consumption of this wild fruit and its great contribution to the nutritional intake of Nigerians, its seasonality limits its availability throughout the year coupled with losses shortly after harvesting due to biochemical and microbial changes. This study therefore aims at determining the effects of storage on the nutritional and antinutritional composition of African star apple fruit (Chrysophyllum africanum) pulp, peel and seed after harvesting.

\section{MATERIALS AND METHODS}

\section{Sample collection and preparation}

Fresh, ripe fruits of African Star Apple (ASA) were harvested from a local farm in Uyo, Akwa lbom State. The fruits were sorted, cleaned and spread on trays for storage at ambient temperature $\left(28 \pm 2^{\circ} \mathrm{C}\right)$ for observation of postharvest changes and determination of nutritional as well as antinutritional parameters on alternate days (1,3 and 5). The pulp, peel and seed of the ASA fruits were removed and kept separately. The cotyledons (inner portion) of the seed were removed from hard outer shell by cracking manually. The fruit pulp, peel and seed were dried in a hot air oven at $65^{\circ} \mathrm{C}$ for 17 hours. The dried samples were grounded into flour using pestle and mortal and then sieved through a 40 mesh sieve (British standard). The flours were packaged in air tight plastic containers prior to use. The dried pulp, peel and seed flours were used for proximate, vitamin and antinutrient analyses except for the moisture content which was determined using the fresh fruits.

\section{Determination of Proximate Composition}

\section{Moisture content}

The moisture content was determined according to the method of AOAC (1995). The weight of a dry sterile evaporating dish was taken after cooling in a desiccator. Five (5) grams of each sample were weighed into preweighed dry evaporating dish. The dish and the content were reweighed before placing them in a hot air oven (J.P. Selecta 200/243) at a temperature of $105^{\circ} \mathrm{C}$ for 3 hours. After drying, the dish and the content were allowed to cool in a desiccator containing silica gel. The dish and the dry samples were reweighed. The procedure of drying was repeated three times until a constant weight was obtained. The moisture content was calculated as a percentage weight loss after drying as follows:

$\%$ Moisture content $=$

$$
\frac{\left(W_{1}\right)\left(W_{2}\right) \times 100}{\left(W_{3}\right)}
$$

$\%$ Moisture content $=$

Weight of original sample Weight of dry sample X100 Weight of original sample

\section{Ash content}

A crucible with lid was ignited in an oven at a temperature of $105^{\circ} \mathrm{C}$ for $1 \mathrm{hr}$. It was transferred to a desiccator to cool and weighed. Five (5) grams of finely ground ovendried sample were placed in a muffle furnace (Naberthern $\mathrm{GmbH} 20$ ) at a temperature of $550^{\circ} \mathrm{C}$ until the sample turned completely into ash. The crucible was allowed to cool to room temperature in a desiccator, reweighed and the weight difference was determined as percent weight loss as follows:

$\%$ Ash $=\frac{\text { Weight of ash } \times 100}{\text { Weight of original sample }}$

\section{Crude Protein}

Crude protein of the samples was determined using Micro-Kjeldahl method according to AOAC (1995).

\section{Digestion}

Two (2) $\mathrm{ml}$ of the sample was accurately weighed into a standard $250 \mathrm{ml}$ Kjeldahl flask containing $1.5 \mathrm{~g} \mathrm{CuSO}_{4}$ and $1.5 \mathrm{~g} \mathrm{Na}_{2} \mathrm{SO}_{4}$ as catalysts and $5 \mathrm{ml}$ of concentrated $\mathrm{H}_{2} \mathrm{SO}_{4}$. The digestion flask was placed in the digestion rack and heated gently to avoid frothing for $2 \frac{1}{2} \mathrm{hr}$ until a clear bluish solution was obtained. The digest was allowed to cool and diluted with $20 \mathrm{ml}$ of distilled water and made up to $50 \mathrm{ml}$.

\section{Distillation}

Twenty (20) $\mathrm{ml}$ of the digest was transferred into a micro Kjeldahl distillation apparatus with anti-bumping chips, to which $10 \mathrm{ml}$ of $40 \% \mathrm{NaOH}$ solution was added. The mixture was steam- distilled and the liberated ammonia collected into a $100 \mathrm{ml}$ conical flask containing $10 \mathrm{ml}$ solution of saturated boric acid to which two drops of a mixed indicator had been added. The tip of the condenser was immersed in the boric acid-doubleindicator solution. Distillation continued until about twothird of the original volume was obtained. 


\section{Titration}

The tip of the condenser was rinsed with a few mls of distilled water into the distillate and titrated against $0.1 \mathrm{NHCl}$ solution until a purple to pink colour was obtained. A blank determination was similarly carried out as described above. The crude protein was obtained by multiplying the percentage (\%) nitrogen content by a factor (6.25) to get the weight of protein.

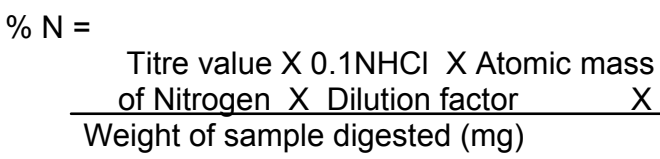

Crude Protein $=\% \mathrm{~N} \times$ Conversion factor (6.25)

\section{Crude Fat}

The method described by AOAC (1995) was adopted. Three (3) grams of the sample were accurately weighed into an extraction thimble which had already been washed and dried in an oven and plugged lightly with cotton wool. Fifteen (15) $\mathrm{ml}$ of petroleum ether (boiling point $60-80^{\circ} \mathrm{C}$ ) was poured into a $500 \mathrm{ml}$ capacity round bottom flask placed on a heating mantle. The Soxhlet apparatus was assembled and allowed to reflux for about 4 hours. The weight of the lipid obtained after evaporating the solvent from the extract gave the weight of the lipid present in the samples as follows:

$\%$ Crude Fat $=$ Weight of fat $X 100$

\section{Crude Fibre}

Weight of sample

Crude fibre was equally analysed according to AOAC (1995). Two (2) gram of defatted sample was used for fibre determination. The defatted sample was obtained by extraction of fat material with petroleum ether for 2 hours. The sample was boiled under reflux for 30 minutes with $200 \mathrm{ml}$ of a solution containing $1.25 \mathrm{~g} \mathrm{H}_{2} \mathrm{SO}_{4}$ per $100 \mathrm{ml}$ solution and $1.25 \mathrm{~g} \mathrm{NaOH}$ solution. The solution was filtered using cotton cloth on a fluted funnel and washed with boiling water until the washings were no longer acidic. The residue was finally washed with methanol and transferred into a pre-weighed crucible and oven-dried at $105^{\circ} \mathrm{C}$. The sample was incinerated in a muffle furnace at $500^{\circ} \mathrm{C}$, allowed to stand at this temperature $2 \mathrm{hr}$ and later cooled in a desiccator and weighed. The loss in weight after incineration multiplied by 100 gave the percentage of crude fibre as follows:

$\%$ Crude Fibre $=$

(Weight of crucible + sample after incineration) Weight of empty crucible X100 Weight of original sample

\section{Carbohydrate}

The total carbohydrate contents of the samples were determined by difference. The sum of the percentage crude fat, crude protein, ash and moisture content were subtracted from $100 \%$, that is,

$\%$ Carbohydrate $=100-(\%$ Crude Fat $+\%$ Crude

Protein $+\%$ Ash $+\%$ Moisture content)

\section{Estimation of Calorific Value (Energy)}

The calorific value of the samples was calculated by Atwater factor method as described by Osborne and Voogt (1978). The value of the protein, carbohydrate and fat was multiplied by 4,4 and $9 \mathrm{Kcal}$, respectively and their sum was taken as the total energy.

\section{Determination of Ascorbic acid (Vitamin C)}

The titration method was used as described by Osborne and Voogt (1978). One gram (1g) each of sample was weighed into test tubes. $1 \mathrm{ml}$ of ascorbic acid stock standard was pipetted into a separate test tube as a standard. $1 \mathrm{ml}$ of trichloreacetic acid (TCA) solution was placed in another test tube to serve as blank. $10 \mathrm{ml}$ TCA solution was added to the sample tubes. I $\mathrm{ml}$ of ditrophenyl hydrazine-thiourea-copper sulphate (DTCS) reagent was added to all the tubes and caped. The tubes were incubated in a water bath at $37^{\circ} \mathrm{C}$ for 3 hours. They were removed from the water bath and chilled for $10 \mathrm{~min}$ in an ice bath while shaking slowly, $2 \mathrm{ml}$ of cold $12 \mathrm{M}$ $\mathrm{H}_{2} \mathrm{SO}_{4}$ was added to all the test tubes. The spectrophotometer was adjusted with the blank to read zero absorbance at $520 \mathrm{~nm}$. The absorbancies of standard and test samples were also read. The results were calculated as follows:

Vitamin $C(\mathrm{mg} / 100 \mathrm{~g})=$

Absorbance of test samples X Concentration of standard Absorbance of standard $X$ Weight of sample

\section{Determination of Mineral Elements}

Calcium and magnesium were determined using atomic absorption spectrophotometer while sodium and potassium were determined using flame photometer (AOAC, 1995).

\section{Determination of Anti-nutrients}

\section{Hydrocyanide}

The standard method of AOAC (1995) was used in the determination of hydrocyanide content of samples. Five (5) gram of each samples were soaked in water for $2 \mathrm{hr}$, after which the liberated cyanide was extracted by steam distillation into $2.5 \% \mathrm{w} / \mathrm{v} \mathrm{NaOH}$ to which $8 \mathrm{ml}$ of $6 \mathrm{~N}$ ammonium hydroxide was added. $0.02 \mathrm{~N}$ silver nitrate 
38 Afr. J. Food Sci. Technol.

Table 1. Proximate composition of African star apple pulp, peel and seed

\begin{tabular}{llllllll}
\hline Sample & $\begin{array}{l}\text { Moisture } \\
\text { Content (\%) }\end{array}$ & $\begin{array}{l}\text { Ash } \\
(\%)\end{array}$ & $\begin{array}{l}\text { Crude } \\
\text { Protein (\%) }\end{array}$ & $\begin{array}{l}\text { Crude } \\
\text { Fibre (\%) }\end{array}$ & $\begin{array}{c}\text { Crude Fat } \\
(\%)\end{array}$ & $\begin{array}{l}\text { Carbohydrate } \\
(\%)\end{array}$ & $\begin{array}{l}\text { Energy } \\
(\%)\end{array}$ \\
\hline PULP & & & & & & & \\
Day 1 & $36.45 \pm 0.53^{\mathrm{c}}$ & $2.65 \pm 0.25^{\mathrm{c}}$ & $6.06 \pm 0.06^{\mathrm{b}}$ & $2.54 \pm 0.16^{\mathrm{e}}$ & $16.02 \pm 0.17^{\mathrm{b}}$ & $36.29 \pm 0.14^{\mathrm{cd}}$ & $313.49 \pm 0.14^{\mathrm{c}}$ \\
Day 3 & $41.60 \pm 1.41^{\mathrm{b}}$ & $2.91 \pm 0.08^{\mathrm{b}}$ & $6.31 \pm 0.26^{\mathrm{a}}$ & $2.71 \pm 0.12^{\mathrm{d}}$ & $17.72 \pm 0.33^{\mathrm{a}}$ & $28.65 \pm 0.07^{\mathrm{de}}$ & $299.33 \pm 0.14^{\mathrm{g}}$ \\
Day 5 & $46.69 \pm 1.07^{\mathrm{a}}$ & $2.93 \pm 0.06^{\mathrm{b}}$ & $5.73 \pm 0.11^{\mathrm{c}}$ & $2.89 \pm 0.10^{\mathrm{c}}$ & $17.53 \pm 0.11^{\mathrm{a}}$ & $24.56 \pm 0.11^{\mathrm{e}}$ & $278.93 \pm 0.32^{\mathrm{c}}$ \\
PEEL & & & & & & & \\
Day 1 & $35.31 \pm 0.27^{\mathrm{d}}$ & $3.67 \pm 0.07^{\mathrm{a}}$ & $3.88 \pm 0.08^{\mathrm{d}}$ & $3.67 \pm 0.07^{\mathrm{a}}$ & $15.25 \pm 0.10^{\mathrm{c}}$ & $38.19 \pm 0.09^{\mathrm{cd}}$ & $305.61 \pm 0.24^{\mathrm{e}}$ \\
Day 3 & $37.02 \pm 0.03^{\mathrm{c}}$ & $3.02 \pm 0.08^{\mathrm{b}}$ & $3.10 \pm 0.05^{\mathrm{e}}$ & $2.92 \pm 0.07^{\mathrm{c}}$ & $15.16 \pm 0.09^{\mathrm{c}}$ & $38.79 \pm 0.17^{\mathrm{cd}}$ & $303.90 \pm 0.25^{\dagger}$ \\
Day 5 & $36.38 \pm 0.08^{\mathrm{c}}$ & $3.10 \pm 0.10^{\mathrm{b}}$ & $2.02 \pm 0.08^{\mathrm{g}}$ & $3.05 \pm 0.05^{\mathrm{b}}$ & $13.50 \pm 0.05^{\mathrm{d}}$ & $41.93 \pm 1.12^{\mathrm{c}}$ & $297.29 \pm 0.20^{\mathrm{h}}$ \\
SEED & & & & & & & \\
Day 1 & $28.62 \pm 0.08^{\mathrm{e}}$ & $1.40 \pm 0.05^{\mathrm{d}}$ & $2.37 \pm 0.08^{\mathrm{f}}$ & $1.36 \pm 0.05^{\mathrm{f}}$ & $7.33 \pm 0.07^{\mathrm{f}}$ & $58.59 \pm 0.40^{\mathrm{b}}$ & $310.64 \pm 1.48^{\mathrm{d}}$ \\
Day 3 & $28.14 \pm 0.05^{\mathrm{e}}$ & $1.10 \pm 0.05^{\mathrm{e}}$ & $2.35 \pm 0.06^{\mathrm{d}}$ & $0.95 \pm 0.05^{\mathrm{g}}$ & $7.37 \pm 0.16^{\mathrm{f}}$ & $58.59 \pm 0.32^{\mathrm{b}}$ & $316.84 \pm 0.31^{\mathrm{d}}$ \\
Day 5 & $27.78 \pm 0.08^{\mathrm{e}}$ & $0.80 \pm 0.05^{\mathrm{f}}$ & $2.45 \pm 0.05^{\mathrm{f}}$ & $0.78 \pm 0.04^{\mathrm{h}}$ & $7.80 \pm 0.05^{\mathrm{e}}$ & $60.39 \pm 0.07^{\mathrm{a}}$ & $321.57 \pm 0.20^{\mathrm{a}}$ \\
\hline
\end{tabular}

Values represent mean \pm standard deviation of triplicate determinations on dry matter basis.

Values with the same letter along the same column are not significantly $(p>0.05)$ different.

was used to titrate the mixture to an endpoint that is faint but permanently turbid.

\section{Oxalate}

Oxalate was determined by the standard method of AOAC (1995). Extraction of $3 \mathrm{~g}$ of the samples with water for 3 hours was carried out and $2.5 \mathrm{~g}$ chloride was added to the extracted samples. The precipitated oxalate in each sample was separately washed with $25 \%$ sulphuric acid and subsequently dissolved in water before titrating against $0.05 \mathrm{~N} \mathrm{KMNO}_{4}$ while the absorbance of the extracts was read at $420 \mathrm{~nm}$ and the amount of oxalate estimated by extrapolation.

\section{Phytate}

Phytate was determined using the method of Sudarmadji and Markakis (1977). Ten (10) grams of sample were weighed into the conical flasks and then extracted with 50 $\mathrm{ml}$ of $3 \%$ TCA for 45 min with occasional swirling by hand. The phytate was precipitated as ferric phytate with the solution of ferric chloride. The precipitate was converted to sodium phytate with $3 \%$ solution of $\mathrm{NAOH}$ before digesting with an acid mixture of equal portion of concentrated $\mathrm{H}_{2} \mathrm{SO}_{4}$ and $65 \% \quad \mathrm{ClO}_{4}$. The liberated phosphorus was quantified calorimetrically at $620 \mathrm{~nm}$ after colour development with ammonium molybdate to which sodium sulphate and hydroquinone solutions were added.

\section{Tannin}

Tannin was determined using the method of Sofowora (1993). Ten (10) grams of dried sample was weighed into a $250 \mathrm{ml}$ conical flask and $50 \mathrm{ml}$ of methanol added. The flask was stoppered, shaken and left to stand for $24 \mathrm{hr}$. The content of the flask was shaken after extraction while the solid particles were allowed to settle before titration. I $\mathrm{ml}$ portion of the extract of fresh vanilla $\mathrm{HCl}$ was added into the volume of extract. The mixture was allowed to stand for $20 \mathrm{~min}$ and the absorbance was measured at $520 \mathrm{~nm}$ against the reagent blank.

\section{Statistical analysis}

The data generated were analysed using Analysis of variance (ANOVA). Significance was accepted at $(p<0.05)$. Means that differed significantly were separated using Duncan's multiple range test (DMRT).

\section{RESULTS AND DISCUSSION}

\section{Proximate Composition of African Star Apple Pulp, Peel and Seed}

The effects of storage on proximate composition of ASA pulp, peel and seed in alternate days are shown on Table 1 . There were highly significant $(p<0.05)$ difference in the pulp, peel and seed of the ASA in alternate days for all the parameters analysed.

\section{Moisture content}

The pulp had the highest moisture content in all the storage days when compared to peel and seed. The pulp of day 5 ASA contained $46.69 \%$ moisture which was higher than the 41.60 and $36.46 \%$ of freshly harvested (day 1 ) and day 3 , respectively. This showed that during storage ripening continued and as the storage days progressed the moisture content of the ASA pulp increased. These values were lower than (66.67\%) moisture content reported by Edem and Dosunmu (2011) but higher than the values 31.97 and $35 \%$ reported by Chukwumalume et al. (2010); Akubor et al. (2013) respectively. This trend was observed in ASA peel in all the storage days. There was increase in moisture content 
of peel which ranged from $35.31 \%$ (day 1 ) to $37.02 \%$ (day 5). There was a lower moisture content compared to $47.95 \%$ reported for the peel by Ukana et al. (2012) while the ASA seed had the lowest moisture content of $28.62 \%, 28.14 \%$ and $27.78 \%$, respectively as the ripening days progressed. This finding was lower than $20.06 \%$ reported by Akubor et al. (2013) for the ASA seed. There was no significance $(p>0.05)$ difference in the moisture content of the seeds as the day of storage progressed. Low moisture content of the matured seed means it can be stored for a longer period than the pulp and peel because of its better resistance to microbial attack (Ukana et al., 2012).

\section{Ash content}

Ash content increased in the pulp with ripening while that of the peel and seed decreased. The ash content of the ASA pulp, peel and seed were 2.65, 2.91 and $2.93 \%$; $3.67,3.10$ and $3.02 \% ; 1.40,1.10$ and $0.80 \%$, respectively. These are respectively close to the values obtained by Ukana et al. (2012) for the structural areas studied. The results indicated that the peel had the highest ash content which decreased as the day progressed. Ash content indicates the amount of inorganic matter and oxides present in the sample.

\section{Crude Protein content}

The ASA pulp of the days 1,3 and 5 had the highest protein content of $6.06,6.31$ and $5.73 \%$, respectively, followed by the peel with the values of $3.88,3.10$ and $2.02 \%$, respectively while the seed had the lowest $(2.37$, 2.35 and $2.45 \%$ ) as the storage days progressed. There was a significant $(p<0.05)$ difference in the crude protein content of the pulp and peel while there was no significant $(p<0.05)$ difference in the ASA seed. These values were higher than the crude protein contents of ASA peel, pulp and seed of $6.68,4.73$ and $8.75 \%$, respectively reported by Ukana et al. (2012). The low protein content in the samples therefore needs to be supplemented from other sources because protein is useful in the repairing of the worn out tissues, building up of new ones as well as improving the organoleptic properties of food materials.

\section{Crude Fat content}

The crude fat content of ASA pulp and seed increased as storage days progressed while that of peel decreased. The ASA pulp had the highest fat content of 16.02, 17.72 and $17.53 \%$ which makes it a very good source of energy while the seed had the lowest fat content of 7.33, 7.37 and $7.80 \%$. The fat content of ASA peel decreased as the ripening days progressed $(15.25,15.16$ and $13.50 \%$ ). These values are higher than the corresponding values of $8.94,10.00$ and $3.45 \%$, respectively reported by Ukana et al. (2012). Fat is an excellent source of energy, enhance transport of fat soluble vitamins, protect internal tissues and contribute to important cell processes.

\section{Crude Fibre content}

The crude fibre content in the ASA pulp increased after harvesting $(2.54,2.71$ and $2.89 \%)$. The peel had the highest crude fibre content of $3.67,3.05$ and $2.92 \%$ while the seed had the lowest $(1.36,0.95$ and $0.78 \%)$. These values are lower than $1.83,3.00$ and $2.42 \%$, respectively obtained for the ASA peel, pulp and seed by Ukana et al. (2012). The fibre content is an indication that it contains a portion of cellulose, hemicelluloses and lignin. However, low fibre content is also known to reduce the rate of glucose and fat absorption. Hence the low fibre contents in the ASA pulp, peel and seed are advantageous in the absorption of glucose and fat.

\section{Carbohydrate content}

The carbohydrate content in the ASA peel and seed increased while these of the pulp decreased with days of ripening. ASA seed had the highest carbohydrate contents of $58.59,69.93$ and $60.39 \%$ followed by the ASA peel with the values of $38.19,38.79$ and $41.93 \%$ while the ASA pulp had the lowest values of $36.29,28.65$ and $24.56 \%$. The decrease in carbohydrate content of the pulp may be as a result of some enzyme activities on the carbohydrate as the main source of energy during the ripening process.

\section{Energy content}

ASA seed contain the highest energy level of 310.64 , 316.84 and $321.57 \%$ while the pulp had the energy values of $313.49,299.33$ and $278.93 \%$ as against the $305.54,303.90$ and $297.29 \%$ of the peel as the ripening days progressed.

\section{Vitamin C content of African Star Apple Pulp, Peel and Seed}

The day 1 ASA pulp, peel and seed have been found to have the highest vitamin $C$ content of $173.77,107.33$ and $185.63 \mathrm{mg} / 100 \mathrm{~g}$ respectively as shown in Figure 1 . These values were about 100 times that of oranges and 10 times of that of guava or cashew (Pearson, 1976). The values of vitamin C of ASA were very high when compared with the recommended dietary allowances (RDA), their values exceeding the RDA of $75 \mathrm{mg} /$ day of vitamin $C$ for female and male (Rolfes et al., 2009). The high ascorbic acid content of the fruit was believed to contribute greatly to the acidic taste of the fruit, especially when it is not fully ripe and soft. This shows that the fruit could be used to promote healthy living by protecting the body from scurvy. The result also revealed the decrease 
40 Afr. J. Food Sci. Technol.

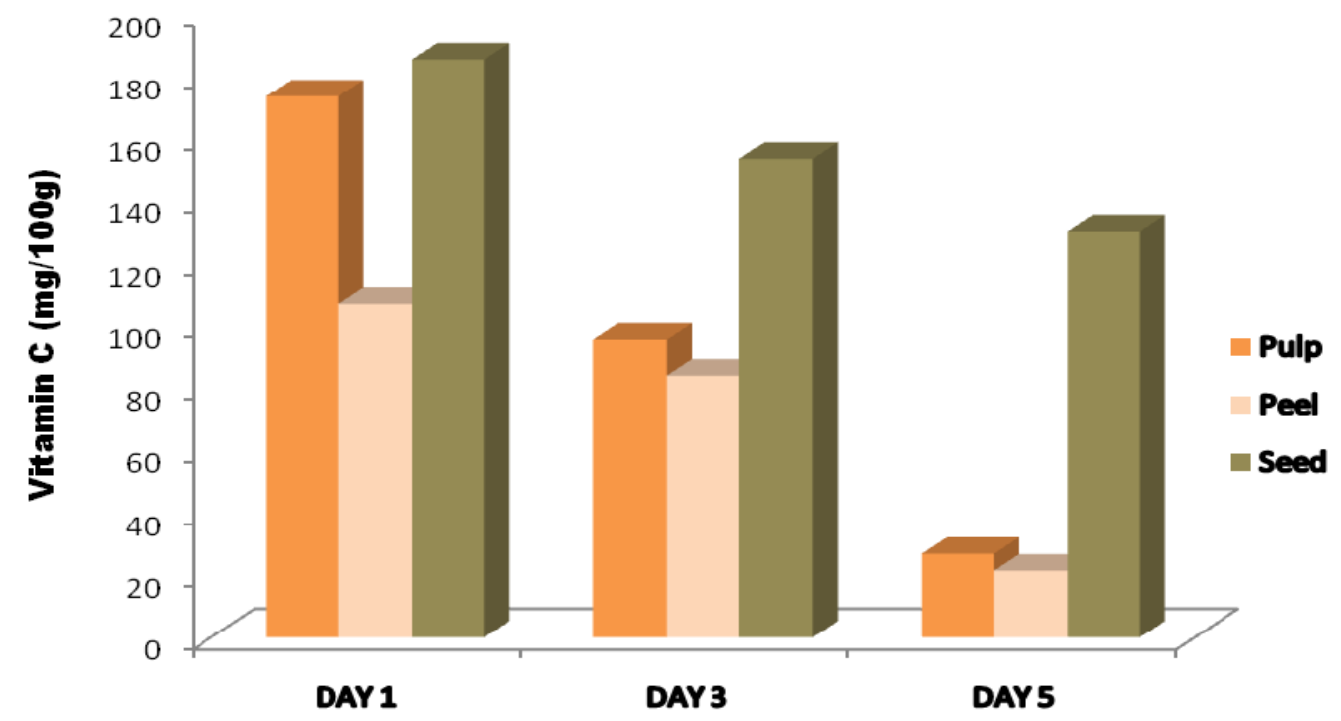

Figure 1. EffectS of postharvest changes on the vitamin $C$ content of African star apple Pulp, peel and seed

Table 2. Mineral composition of African star apple pulp, peel and seed

\begin{tabular}{lllll}
\hline Sample & $\begin{array}{l}\text { Sodium }(\mathbf{N a}) \\
(\mathbf{m g} / \mathbf{1 0 0 g})\end{array}$ & $\begin{array}{l}\text { Potassium }(\mathbf{K}) \\
(\mathbf{m g} / \mathbf{1 0 0 g})\end{array}$ & $\begin{array}{l}\text { Magnesium }(\mathbf{M g}) \\
(\mathbf{m g} / \mathbf{1 0 0 g})\end{array}$ & $\begin{array}{l}\text { Calcium }(\mathbf{C a}) \\
(\mathbf{m g} / \mathbf{1 0 0 g})\end{array}$ \\
\hline PULP & & & & \\
Day 1 & $10.77 \pm 0.21^{\mathrm{d}}$ & $8.60 \pm 0.10^{\mathrm{d}}$ & $3.50 \pm 0.30^{\mathrm{c}}$ & $33.00 \pm 0.10^{\mathrm{a}}$ \\
Day 3 & $10.55 \pm 0.61^{\mathrm{d}}$ & $9.33 \pm 0.16^{\mathrm{c}}$ & $3.28 \pm 0.30^{\mathrm{d}}$ & $30.30 \pm 0.10^{\mathrm{b}}$ \\
Day 5 & $10.10 \pm 0.21^{\mathrm{e}}$ & $9.50 \pm 0.20^{\mathrm{c}}$ & $3.18 \pm 0.20^{\mathrm{c}}$ & $30.21 \pm 0.10^{\mathrm{b}}$ \\
PEEL & & & & \\
Day 1 & $7.03 \pm 0.15^{\dagger}$ & $2.18 \pm 0.06^{\mathrm{e}}$ & $1.83 \pm 0.03^{\mathrm{c}}$ & $23.16 \pm 0.06^{\mathrm{c}}$ \\
Day 3 & $7.02 \pm 0.07^{\dagger}$ & $2.10 \pm 0.06^{\mathrm{e}}$ & $1.15 \pm 0.05^{\dagger}$ & $23.05 \pm 0.05^{\mathrm{c}}$ \\
Day 5 & $5.94 \pm 0.05^{\mathrm{g}}$ & $1.77 \pm 0.07^{\mathrm{f}}$ & $1.07 \pm 0.08^{\mathrm{f}}$ & $23.05 \pm 0.05^{\mathrm{c}}$ \\
SEED & & & & \\
Day 1 & $24.17 \pm 0.16^{\mathrm{c}}$ & $23.19 \pm 0.16^{\mathrm{a}}$ & $13.98 \pm 0.14^{\mathrm{b}}$ & $20.97 \pm 0.15^{\mathrm{e}}$ \\
Day 3 & $28.03 \pm 0.04^{\mathrm{b}}$ & $23.00 \pm 0.14^{\mathrm{a}}$ & $14.15 \pm 0.14^{\mathrm{b}}$ & $21.19 \pm 0.17^{\mathrm{d}}$ \\
Day 5 & $29.21 \pm 0.10^{\mathrm{a}}$ & $21.23 \pm 0.10^{\mathrm{b}}$ & $14.79 \pm 0.12^{\mathrm{a}}$ & $21.03 \pm 0.13^{\mathrm{de}}$ \\
\hline
\end{tabular}

Values represent mean \pm standard deviation of triplicate determinations on dry matter basis.

Values with the same letter along the same column are not significantly $(p>0.05)$ different.

in vitamin C content of ASA pulp, peel and seed as the ripening days progressed. This trend was similar to the observations of Aydin and Kadioglu (2001) and Othman (2009).

\section{Mineral Composition of African Star Apple Pulp, Peel and Seed}

Table 2 presents the results of the mineral analysis. Minerals are very important in the diet because of their diverse functions in the body. They are required for normal growth and other activities of muscles, skeletal development, cellular activity and oxygen transport, chemical reaction in the body and intestinal absorption, fluid balance and nerve transmission, as well as the regulation of acid-base balance.

\section{Sodium ( $\mathrm{Na})$ content}

The sodium content of the ASA pulp and peel decreased as the day progressed while that of the seed increased. The ASA seed had the highest sodium content of 27.14 , 28.09 and $29.21 \mathrm{mg} / 100 \mathrm{~g}$ followed by the pulp with values of $10.77,10.55$ and $10.10 \mathrm{mg} / 100 \mathrm{~g}$ while the peel had the lowest sodium content of 7.03, 7.02 and 5.94 $\mathrm{mg} / 100 \mathrm{~g}$. The mineral is very important in maintaining the body fluid volume, acid-base balance and osmotic equilibrium.

\section{Potassium (K) content}

The seed of ASA had the highest potassium content for day 1,3 and 5 with the values of $23.19,23.00$ and 21.23 
Table 3. Antinutritional composition of African star apple pulp, peel and seed

\begin{tabular}{lllll}
\hline Sample & $\begin{array}{l}\text { HCN } \\
(\mathbf{m g} / \mathbf{1 0 0 g})\end{array}$ & $\begin{array}{l}\text { Oxalate } \\
(\mathbf{m g} / \mathbf{1 0 0 g})\end{array}$ & $\begin{array}{l}\text { Tannin } \\
(\mathbf{m g} / \mathbf{1 0 0})\end{array}$ & $\begin{array}{l}\text { Phytate } \\
(\mathbf{m g} / \mathbf{1 0 0 g})\end{array}$ \\
\hline PULP & & & & \\
Day 1 & ND & $2.14 \pm 0.15^{\mathrm{c}}$ & $0.39 \pm 0.13^{\mathrm{d}}$ & $0.05 \pm 0.07^{\mathrm{d}}$ \\
Day 3 & ND & $1.73 \pm 0.16^{\mathrm{d}}$ & $0.36 \pm 0.13^{\mathrm{d}}$ & $0.06 \pm 0.10^{\mathrm{c}}$ \\
Day 5 & ND & $1.64 \pm 0.10^{\mathrm{d}}$ & $0.31 \pm 0.09^{\mathrm{e}}$ & $0.08 \pm 0.09^{\mathrm{c}}$ \\
PEEL & & & & \\
Day 1 & ND & $4.93 \pm 0.14^{\dagger}$ & $0.34 \pm 0.17^{\dagger}$ & $0.02 \pm 0.10^{\dagger}$ \\
Day 3 & ND & $2.82 \pm 0.08^{\mathrm{g}}$ & $0.32 \pm 0.11^{\mathrm{g}}$ & $0.04 \pm 0.08^{\dagger}$ \\
Day 5 & ND & $2.10 \pm 0.12^{\mathrm{h}}$ & $0.32 \pm 0.06^{\mathrm{d}}$ & $0.05 \pm 0.10^{\mathrm{e}}$ \\
SEED & & & & \\
Day 1 & $0.33 \pm 0.07^{\mathrm{a}}$ & $12.41 \pm 0.16^{\mathrm{a}}$ & $0.79 \pm 0.10^{\mathrm{a}}$ & $0.71 \pm 0.09^{\mathrm{a}}$ \\
Day 3 & $0.31 \pm 0.06^{\mathrm{a}}$ & $12.40 \pm 0.15^{\mathrm{a}}$ & $0.78 \pm 0.09^{\mathrm{b}}$ & $0.69 \pm 0.14^{\mathrm{b}}$ \\
Day 5 & $0.28 \pm 0.06^{\mathrm{a}}$ & $11.97 \pm 0.64^{\mathrm{b}}$ & $0.68 \pm 0.09^{\mathrm{c}}$ & $0.57 \pm 0.14^{\mathrm{b}}$ \\
\hline
\end{tabular}

Values represent mean \pm standard deviation of triplicate determinations on dry matter basis.

Values with the same letter along the same column are not significantly $(p>0.05)$ different.

$\mathrm{mg} / 100 \mathrm{~g}$ respectively followed by that of the pulp with the values of $8.6,9.33$ and $9.50 \mathrm{mg} / 100 \mathrm{~g}$ while the peel had the lowest values of $2.18,2.10$ and $1.77 \mathrm{mg} / 100 \mathrm{~g}$ as the ripening days progressed from 1,3 and 5 respectively.

\section{Magnesium (Mg) content}

The magnesium content of ASA pulp and peel decreased as the days increased with the values of $3.50,3.28$ and $3.18 \mathrm{mg} / 100 \mathrm{~g}$; and $1.83,1.15$ and $1.07 \mathrm{mg} / 100 \mathrm{~g}$ respectively while that of $13.98,14.15$ and 14.79 $\mathrm{mg} / 100 \mathrm{~g}$. The seed had the highest content of magnesium followed by the pulp while the peel has the lowest content of magnesium. These values were lower than $26 \mathrm{mg} / \mathrm{kg}$ and $36 \mathrm{mg} / \mathrm{kg}$ reported by Falade et al. (2003) for $C$. sinensis and A. comusus, respectively.

\section{Calcium (Ca) content}

The calcium content of African star apple increased in the pulp and seed as the days increased with the value of $33.00,30.30$ and $30.21 \mathrm{mg} / 100 \mathrm{~g}$ and $20.97,21.04$ and $21.23 \mathrm{mg} / 100 \mathrm{~g}$ respectively while the calcium content of the peel decreased with the value of 23.16, 23.05 and $23.05 \mathrm{mg} / 100 \mathrm{~g}$. The peel had the highest content of calcium followed by the seed while the pulp had the lowest.

This fruit has the potentials for providing essential nutrients for human nutrition. Since the nutritional activities of any plant are usually traced to the particular elements it contains (Sofowora, 1993). For example, calcium plays a vital role in the constitution of biological systems; its presence in bones provides an animal with the required rigidity and support (Ibarahim et al., 2006). The level of calcium in this fruit is therefore adequate for the required needs of the body.

\section{Anti-nutritional Composition of African Star Apple Pulp, Peel and Seed}

The anti-nutritional composition of African star apple pulp, peel and seed were equally investigated on alternate days of storage and the results calculated in $\mathrm{mg} / 100 \mathrm{~g}$, are shown in Table 3.

\section{Hydrocyanide content (HCN)}

The hydrocyanide content was not detected in the star apple pulp and peel while that of the seed decreased as the days increased with the value of $0.33,0.31$ and 0.28 $\mathrm{mg} / 100 \mathrm{~g}$.

\section{Oxalate content}

The oxalate content of the star apple pulp, peel and seed decreased as the postharvest days increased. The seed had the highest content of oxalic acid: $12.41,12.40$ and $11.97 \mathrm{mg} / 100 \mathrm{~g}$, followed by the peel with the values of 4.93, 2.82 and $2.00 \mathrm{mg} / 100 \mathrm{~g}$ while the pulp had the lowest $(2.14,1.73$ and $1.64 \mathrm{mg} / 100 \mathrm{~g})$. This finding was lower than $4.995 \mathrm{mg} / 100 \mathrm{~g}$ (fruit pulp) reported by Edem and Dosunmu (2011).

\section{Tannin content}

The tannin content decreased as the day increased in the star apple fruit pulp, peel and seed with the value of 0.39 , 0.36 and $0.31 \mathrm{mg} / 100 \mathrm{~g} ; 0.34,0.32$ and $0.32 \mathrm{mg} / 100 \mathrm{~g}$; $0.79,0.78$ and $0.68 \mathrm{mg} / 100 \mathrm{~g}$, respectively. Decrease in tannin content was also reported for guava by Lim et al. (2006). The reduction in tannin could be attributed to the action of polyphenol oxidase enzyme which oxidizes tannin to phenol. Tannins adversely affect protein 
digestibility but its minimum level required to elicit a negative growth response has not been fully established, hence it is still unclear as to what level of it could be harmful (Elemo et al., 2001). However, the level of tannin content in this fruit pulp and peel is low when compared to that of some other plants (Getachew et al., 2013).

\section{Phytate content}

The phytate content increased in the pulp and peel with the values of $0.05,0.06$ and $0.08 \mathrm{mg} / 100 \mathrm{~g} ; 0.02,0.04$ and $0.05 \mathrm{mg} / 100 \mathrm{~g}$ while that of the seed decreased with the values of $0.71,0.69$ and $0.57 \mathrm{mg} / 100 \mathrm{~g}$ as the day progressed. These values were higher than 0.037 $\mathrm{mg} / 100 \mathrm{~g}$ reported by Adepoju and Adeniji (2012) but lower than $0.32 \mathrm{mg} / 100 \mathrm{~g}$ reported by Edem and Dosunmu (2011) for the ASA fruit pulp. The determination of antinutrients in the samples is necessary because their presence can reduce essential nutrients bioavailability. Some of these antinutrients have been found to have protection against some diseases. Phytate has strong binding capacity and forms insoluble complexes with multivalent cations, including calcium, magnesium, sodium and potassium, and thus render them biologically unavailable.

\section{CONCLUSION}

The results from the proximate composition showed that the ASA pulp, peel and seed have greater amount of carbohydrate and crude fat contents during storage period but most of the nutrients were concentrated in the pulp and peel. Vitamin C content of the fruit decreased with increased in ambient storage period, this indicated that the quality and shelf life of fruit is hindered at ambient storage. There is a reduction in the antinutrient composition of the ASA pulp, peel and seed with the seed having a moderate amount of antinutrient. The reduction in the antinutrient composition showed that continuous ripening during storage could also be a way of reducing antinutrients in food samples after harvesting. Mineral elements revealed that ASA pulp and peel contain greater amount of calcium while potassium and sodium were high in the seed. It can therefore be deduced that ASA has a great potential in contributing to the healthy growth and as supplementation in food industries.

\section{REFERENCES}

Achinewu SC (1983). "Ascorbic acid content of some Nigerian Local fruits and vegetables", Qual. Plant. Plant foods Hum. Nutri., pp. 261266.

Adebayo HA, Abolaji AO, Opata TK, Adegbenro IK (2010). Effects of ethanolic leaf extract of Chrysophyllum albidum G. Don biochemical and haematological parameters of albino wister rats. Afr. J. of Biotechnol. 9(14): 2145-2150.

Adepoju OT, Adeniji PO (2012). Nutrient composition and micronutrient potential of three wildly grown varieties of African star apple (Chrysophyllum albidum) from Nigeria. Afr. J. Food Sci. (6):344-351.

Adewoye EO, Salami AT, Taiwo VO (2010). Antiplasmodial and toxicological effects of methanolic bark extract of Chrysophyllum albidum in albino mice. J. of Physiol. and Pathphysiol. 1: 1 - 9.

Adewusi HA (1997). The African star apple (Chrysophyllum albidum) indigenous knowledge from Ibadan, South Western Nigeria. Proceedings of a National Workshop on Potentials of the Star Apple in Nigeria, pp. 25.

Adisa SA (2000). Vitamin C, Protein and mineral contents of African Apple (Chrysophyllum albidum) IN: Proceedings of the 18th annual conference of NIST. (Eds.), pp. $141-146$.

Akubor PI, Yusuf D, Obiegunam JE (2013). Proximate composition and some functional properties of flour from the kernel of African star apple (Chrysophyllual albidum ). Int. J. of Agric. Polic. and Res. Vol.1 (3), pp. 062-066.

Akubugwo IE, Ugbogu AE (2007). Physicochemical studies on oils from five selected Nigerian plant seeds. Pak. J. of Nutr. 6: 75-78.

Amusa NA, Ashaye OA, Oladapo MO (2003). Biodeterioration of the African Star apple (Chrysophyllum albidum) in storage and the effect on its food value. Afr. J. Biotechnol. 2; 56 - 57.

AOAC (1995). Association of Official Methods of Analysis (15th ed.) Washington, DC.

Arindam D, Dato I, Badaruddin N, Amiya B (2010) A brief review on Chrysophyllum cainito. J. of Pharmacognosy \& Herbal Formulations. 1: $1-4$.

Aydin N, Kadioglu A (2001). Changes in the chemical composition, polyphenol oxidase and peroxidase activities during development and ripening of medlar fruits (Mespilus germanica L.). Bulg. J. Plant Physiol. 27(3-4): 85-92.

Chukwumalume RC, Garba SA, ljah L, Agary A (2010). Chemical Composition Of African Star Apple (Chrysophyllum albidum) Fruit Juice, Book of Extended Abstract of the 34th Annual Conference and Annual General Meeting of Nigerian Inst. of Food Sc. and Technol., pp. 238-239.

Duyilemi OP, Lawal IO (2009). Antibacterial activity and phytochemical screening of Chrysophyllum albidum leaves. Asian J. of Food and Agro-Industry, Special Issue: S75-S79

Edem CA, Dosunmu MI (2011). Chemical evaluation of proximate composition, ascorbic acid and anti-nutrients content of African star apple (Chrysophyllum africanum) fruit. IJRRAS (9) 1:146-149.

Edem DO, Eka OO, Ifon ET (1984). Chemical evaluation of nutritive value of the fruit of African star apple. Food Chem. 14: 303-311.

Egunyomi A, Fasola T, Oladunjoye R (2005). Charring Medicinal Plants: A Traditional Method of Preparing Phytomedicines in Southwestern Nigeria. Ethnobotany Res. and Applic. 3: 261-265

Elemo BO, Elemo GN, Agboola, OO, Oyedun AB (2001). Studies on some antinutritive factors and in-vitro protein digestibility of Thaumatococcus daniella (Benth) waste. Nigerian J. of Biochem. and Mol. Biol. 16:43-46.

Falade OS, Olatunbosun OA, Oladipo AA, Tunbosun A, Adewusi SRA (2003). The level of organic acids in some Nigerian fruits and their effect on mineral availability in composite diets. Pak. J. Nutr. 2:8288.

FAO (1989). Food and Agricultural Organisation of United Nations. Household food security and forestry: An analysis of socioeconomic issues. FAO, Rome.

Getachew AG, Asfaw Z, Singh V, Woldu Z, Baidu-Forson JJ and Bhattacharya, S (2013). Dietary values of wild and semi-wild edible plants in Southern Ethiopia. Afr. J. Food, Agric. Dev. (13) 2:74857503.

Ibrahim G, Mahmud N, Yaro AH, Ahmed A (2006). Phytochemical and toxicology evaluation of the stem bark of Ficus sycomprus LINN (Moraceae). Biol. and Environ. Sci. J. for the Tropics 3(3):37-40.

Islam A (2002). "Kiraz" Cherry laurel (Prunus laurocerasus) New Zealand J. Crop Horticult. Sci. 30:301- 302.

Keay RW (1989). Trees of Nigeria. A review version of Nigerian trees (vol.1-2) editions. Calrendon press, Oxford, pp. 476. 
Lim YY, Lim TT and Tee JJ (2006). Antioxidant properties of guava fruit: Comparism with some local fruits. Sunway Acad. J. 3:9-20

Oboh IO, Aluyor EO, Audu TOK (2009). Use of Chrysophyllum albidum for the removal of metal ions from aqueous

42 Afr. J. Food Sci. Technol.

solution. Scientific Research and Essay. 4(6):632-635.

Okafor JC (1981). Woody plants of nutritional importance in traditional farming system of the Nigeria humid tropics Ph.D diss. University of Ibadan.

Okigho BN (1978). "Cropping systems and related research in Africa". Association for the advancement of agricultural sciences in Africa (AASA) 10th Anniversary issue.

Osborne DR, Voogt P (1978). The analysis nutrients in foods. Academic press, London.

Othman OC (2009). Physical and chemical composition of storageripened papaya (Carica papaya) fruits of Eastern Tanzania. Tanz. J. Sci. 35:47.56.

Pearson D (1976). Chemical Analysis of Foods. Churchill Livingstone, London, pp. 181.
Rolfes SR, Pinna K, Whitney E (2009). Understanding normal and clinical nutrition. 8th Edn Wadsworth Cengage Learning, pp. 383.

Sofowora A (1993). Medicinal Plants and Traditional Medicine in Africa 2nd Edn.Spectrum Books Limited, Ibadan, Nigeria, pp. 14-34.

Sudarmadji S, Markakis, P (1977). The phytate and phytase of soybean Tempeh. J. Sci. Food Agric., 28(4): 381-383.

Ugbogu OC, Akukwe AR(2008). The antimicrobial effect of oils from Pentaclethra macrophylla Bent, Chrysophyllum albidum G. Don and Persea gratissima Gaerth $\mathrm{F}$ on some local clinical bacteria isolates. Afr. J. of Biotechnol. 8 (2): 285-287.

Ukana DA, Aniekan EA, Godwin NE (2012). Evaluation of proximate compositions and mineral elements in the star apple peel, pulp and seed. J. Basic. Appl. Sci. Res. 2(5)4839-4843.

How to cite this article: Florence Abolaji Bello and Adiaha Abigail Henry (2015).Storage effects and the postharvest quality of African star apple fruits (Chrysophyllum africanum) under ambient conditions Afr. J. Food Sci. Technol. 6(1):3543 